\begin{tabular}{|l|l|l||}
\hline \multicolumn{2}{|c|}{ PublisherInfo } \\
\hline \hline PublisherName & $:$ & BioMed Central \\
\hline \hline PublisherLocation & $:$ & London \\
\hline \hline PublisherImprintName & $:$ & BioMed Central \\
\hline \hline
\end{tabular}

\title{
Role of BAX in apoptosis
}

\begin{tabular}{|l|l|l||}
\hline \multicolumn{2}{|c||}{ ArticleInfo } \\
\hline \hline ArticleID & $:$ & 127 \\
\hline \hline ArticleDOI & $:$ & $10.1186 /$ ar-2000-66869 \\
\hline \hline ArticleCitationID & $:$ & 66869 \\
\hline \hline ArticleSequenceNumber & $:$ & 84 \\
\hline \hline ArticleCategory & $:$ & Paper Report \\
\hline \hline ArticleFirstPage & $:$ & 1 \\
\hline \hline ArticleLastPage & $:$ & 3 \\
\hline \hline & $:$ & RegistrationDate : 2000-12-13 \\
ArticleHistory & $:$ & OnlineDate \\
\hline \hline ArticleCopyright & $:$ & Current Science Ltd2000-12-13 \\
\hline \hline ArticleGrants & $:$ & \\
\hline \hline ArticleContext & $:$ & 130753311 \\
\hline \hline
\end{tabular}


Richard Brasington,, Affl

Aff1 Washington University School of Medicine, St Louis, USA

\section{Keywords}

Antineoplastic agents, apoptosis, BAX, Bcl-2

\section{Context}

BAX is the key member of the Bcl-2 family, which plays a critical role in apoptosis in cancer cells. Drug-induced apoptosis in cancer cells is believed to be an important mechanism of action of antineoplastic agents. The goal of this study is to clarify the role of BAX in drug-induced apoptosis in human epithelial cells, the source of the majority of malignancies.

\section{Significant findings}

Human colorectal cancer cells lacking functional BAX genes were completely resistant to apoptosis induced by sulindac and indomethacin, but only partially resistant to apoptosis induced by 5-fluorouracil. Nonsteroidal anti-inflammatory drugs (NSAIDs) appear to induce apoptosis by increasing the ratio of $\mathrm{BAX}$ to $\mathrm{Bcl}-\mathrm{X}(\mathrm{L})$, by decreasing the expression of $\mathrm{Bcl}-\mathrm{X}(\mathrm{L})$. Most colorectal cancer cell lines display similar BAX:Bcl-X(L) ratios.

\section{Comments}

This study provides an important insight into the mechanism of drug-induced apoptosis of human colorectal cancer cells, which may be important in the development of antineoplastic therapies. Although NSAIDs may have benefit in preventing hereditary colon cancer, the development of BAX mutations in such cancers would abrogate the protective effect of NSAIDs.

\section{Methods}


Apoptosis induction in mutant human colorectal cell lines

\section{References}

1. Zhang L, Yu J, Park BH, Kinzler KW, Vogelstein B: Role of BAX in the apoptotic response to anticancer agents. Science. 2000, 290: 989-992.

This PDF file was created after publication. 